\title{
A Discussion on Developing Students' Communicative Competence in College English Teaching in China
}

\author{
Fan Fang \\ English Language Center, Shantou University, Shantou, Guangdong, P.R. China \\ Email: ffang@stu.edu.cn
}

\begin{abstract}
With the spread and development of English around the world and its increased use in China, research about improved methods to develop college students' English level has become of great importance. This has promoted changes in both the teaching and learning process. This paper analyzes the necessity and feasibility of developing students' communicative competence in College English Teaching (CET) and also discusses the advantages and challenges of Communicative Language Teaching (CLT) for CET. A questionnaire is used to determine students' understanding of the term of communicative competence, as well as to discover their opinions about teaching and learning within the framework of fostering their communicative skills. As it seems an appropriate time to implement communicative teaching approach in Chinese universities, this paper also raises the issue of future reform based on current CET in China.
\end{abstract}

Index Terms —English language teaching, communicative competence, college English teaching

\section{ENGLish Language Teaching IN China}

It is apparent that in the 21st century, the trend of globalization is leading to closer relationships between countries. Of all the different languages, English, as a global/international language (EGL/EIL) or a Lingua Franca (ELF), is widely used in communication between people and countries. The English language has spread and developed globally, which is a fact that cannot be ignored. In China, for instance, McArthur (2002: 353) has pointed out the importance of English, by stating that "English is massively the principal foreign language taught (and sought after) in the PRC (People's Republic of China), where it has high status as the global medium of education, travel, entertainment, e-communication, and business."

As the main foreign language taught and employed in communication with foreigners, the use of English has dramatically increased in China, especially in the last decade. The number of English learners in this country exceeds 250 million (Chen \& Hu, 2006) nowadays. However, English Language Teaching (ELT) in China has not affected the traditional teaching model whereby students learn English just to pass exams and teachers lecture mainly to help students achieve this goal. The result is that students do not have enough English to communicate effectively with others. In China, this is called "Dumb English" or "Deaf English"1. Obviously, students" overall skills cannot be enhanced, especially for students at the college and university level. In order to improve the situation based on need analysis, the Chinese Ministry of Education published College English Curriculum Requirements (2007), which states that:

The objective of College English is to develop students' ability to use English in an all-round way, especially in listening and speaking, so that in their future work and social interactions they will be able to exchange information effectively through both spoken and written channels, and at the same time they will be able to enhance their ability to study independently and improve their cultural quality so as to meet the needs of China's social development and international exchanges.

Though such a teaching method cannot be widely implemented as expected currently, this statement can be seen as a measure of reform for College English Teaching (CET) in order to develop university students' communicative competence.

\section{THE CONCEPT OF COMMUNICATIVE COMPETENCE AND ITS DEVELOPMENT}

One of the earliest concepts of communicative competence was introduced by Hymes (1972). He believed that the ability to communicate properly should be cultivated in language teaching. Students should learn how to use a language in their daily communication in order to demonstrate their mastery of a language.

Hymes' (1972) theory of communicative competence has been widely acknowledged and accepted by English

\footnotetext{
1 "Dumb English" (learners cannot express themselves) or "Deaf English" (learners cannot make themselves understood) can both refers to "a consequence that students cannot use English to communicate with others".
} 
educators and scholars (Canale \& Swain, 1980; Kunschak, 2004; McKay, 2002). As the concept of "communicative competence" is being further developed, different language skills such as linguistic, sociolinguistic, discourse, strategic and pragmatic competences are receiving increasing focus (Davies, 2005; Hedge, 2000). Kramsch (2006, p.36) states that "language learning, as the acquisition of communicative competence, is now defined as the expression, interpretation and negotiation of meaning between two interlocutors or between a text and its readers".

It is believed that one of the main goals of both ELT and CET in China nowadays is to develop students' communicative competence, as more students will regard English as a communicating tool after graduation. If students can use the English knowledge, skills and cultural aspects they have learned to communicate with people of different cultural backgrounds in real language contexts, they are then using English as a communication tool.

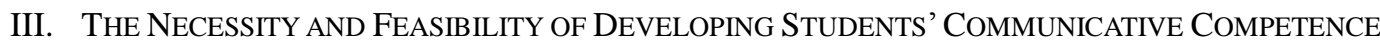

After the publication and implementation of the College English Curriculum Requirements (2007), both listening and speaking skills have become key criteria by which to measure the success of CET in China. Thus, we can see that the ultimate purpose of CET in China today is not just to have students pass exams by blindly using the "cramming" teaching method in large classrooms.

Generally speaking, students who major in English are a minority at Chinese universities. More students will use English in future careers such as business, law, and journalism. English will be used as a tool to communicate or negotiate with different people after their graduation. In other words, the popularity of English worldwide provides a clear reason to reform ELT in China, get rid of exam-oriented education, and to focus on developing students' listening and speaking skills so they learn to communicate effectively with others.

Improving college English teachers' abilities and qualifications necessarily means improving college students' communicative skills. Teachers should participate in designing CET syllabi and be aware of the objectives of CET. Many Chinese who have earned master and doctoral degrees related to the English language/literature or Teaching English to Speakers of Other Languages (TESOL) become valuable resources for CET. Many such teachers are overseas returnees and are both enthusiastic and better understand the English language and culture. Therefore, the prospective and reformative consciousness of such teachers gives CET new opportunities and passions.

University facilities and resources are also gradually improving comparing with the past decade. Multimedia teaching provides a platform for developing speaking skills by stimulating students' interest and participation in class (Yang \& Fang, 2008). Moreover, CET in China today is more student-centered. Instructors can mostly act as catalysts in the process of communicative language teaching (CLT). As Kramsch (2006, p.38) have pointed out, "[teachers] set up the conditions under which learners learn to learn. The teacher is to be a 'guide on the side, rather than sage on the stage"'.

We should also be aware of the different attitudes of teachers and students toward English teaching and learning. It cannot be denied that many college students still do not have specific reasons for learning English, or they learn English simply to pass exams. Therefore, it is not an easy task to implement a project to develop university students' communicative competence.

\section{The Advantages of DeVeloping Students' Communicative Competence}

While developing their speaking abilities and increasing their vocabulary level, students simultaneously develop their listening skill and also gain confidence during the process of communication. It is apparent that an English context is automatically created during various activities when implementing CLT while English is used as the medium for students to communicate with each other. The English context can help students cultivate their sense of the language, and create an atmosphere where students can improve their English ability. CLT provides students an opportunity to speak and share ideas in a relatively relaxing way. Therefore, students become the protagonists in the classroom, and their initiative and motivation are both enhanced. A problem that the lack of an English context may block students' English study can be solved by implementing this teaching method, because CLT not only focuses on developing students' listening and speaking skills of English, but also reading and writing skills.

CLT can introduce new teaching methods, creating a diversified teaching process. Teachers can use various resources to help students develop their communicative skills, which is another manifestation of the diversity of the teaching method. For example, English teachers can use pictures to promote group discussions, thereby helping students understand the informational and cultural background of various topics. Games can also be used to help students learn vocabulary and practice their writing skills. More specifically, teachers can help students create an English context when teaching grammar and Western culture. They can ask students questions such as "If you had been born in the United States, how would your life be different now?" "What experiences would you have had?" "What things would not have happened to you that actually have?" During group discussions, students not only practice their spoken English, but also learn about different cultures. Grammar can also be practiced during this process.

However, the challenges of CLT cannot be ignored and the traditional ELT model in China may not be easily changed. This is why we must also discuss some problems and challenges of CLT in China.

\section{The Challenges of DeVeloping Students' Communicative Competence}


First, a traditional limitation to developing students' communicative competence is the inadequate interaction between teachers and students. Teachers simply spend much time lecturing while students take notes and seldom participate in class. The relatively tedious test-based teaching method makes students reluctant to freely participate in classroom discussions. Therefore, the communicative teaching approach is still on a journey from theory to practice in Chinese universities. Currently, teachers and students do not fully realize the benefits of enhancing the latter's communicative competence in the process of ELT. We should also note that the number of students in English classes is greater than expected (generally around 40 to 60 in one class), compared to the number of English majors (generally around 20 to 30 in one class). Therefore, greater numbers of students do not have enough opportunity to communicate with each other in English. Students' lack of initiative may also influence the effectiveness of teaching.

Second, another obstacle to implementing CLT is the method of evaluating CET in China. College English Test Band 4 and Band $6^{2}$ are still important evaluation standards to test students who are not English majors. Currently, the evaluation reforms pay more attention to developing students' integrated ability. Although at some Chinese universities (such as Fudan University, Jilin University, and Shantou University), Band 4 and Band 6 certificates are no longer related to a student's degree, the overwhelming effect of the evaluation test is to put pressure on students to learn English, making the system of connecting certificates to improve job opportunities hard to change. Students who take the oral English proficiency tests are mostly higher-intermediate students, who comprise a small portion of the university population. Although some universities pay more attention to developing students' communicative competence, the traditional assessing system is still ingrained, and the dichotomy between "accuracy" and "fluency" is still worth considering if this teaching method will be more widely implemented in China.

Another challenge of CLT may be related to the students themselves. CET is mostly used for students who are not English majors, who may have different opinions about English teaching and learning. The lack of input and output of English leads to a lack in students' reading vocabulary skill, which might make it difficult to successfully implement this teaching method. Furthermore, different attitudes toward learning English may also impede students' learning. Therefore, it is necessary that teachers and students create a good balance between English teaching and learning, thus allowing college students' communicative competence to gradually improve.

\section{QUESTIONNAIRE}

\section{A. Description of the Questionnaire}

A questionnaire was applied to explore college students' understanding of CLT and their need to learn English at university. A medium-sized tertiary university was chosen because it is located in Southern China, where ELT has undergone some reform in order to focus on the communicative teaching approach and developing students' critical thinking. Altogether 150 participants answered the questionnaire; 87 respondents were lower-intermediate students and 63 were higher-intermediate. Both groups of students were asked to answer the questionnaire during a break in their English class or during free periods. It is hoped that the results of the questionnaire will reflect students' opinions about the implementation and effectiveness of the communicative teaching approach in teaching and learning English.

\section{B. Discussion}

\footnotetext{
${ }^{2}$ College English Test Band 4 and Band 6 is a testing system designed to test the English level of college and university students who do not major in English. Certificates have been regarded as one of the key elements for students to gain better jobs after graduation.
} 
TABLE 1

STUDENT OPINIONS ABOUT COMMUNICATIVE COMPETENCE AND CET

\begin{tabular}{|c|c|c|c|c|c|}
\hline Questions & Options & $\begin{array}{c}\text { Inter. } \\
\text { Students }\end{array}$ & \%age & $\begin{array}{c}\text { Adv. } \\
\text { Students }\end{array}$ & \%age \\
\hline $\begin{array}{l}\text { Have you ever heard the term } \\
\text { "communicative competence"? }\end{array}$ & Yes & 26 & 29.88 & 17 & 26.98 \\
\hline $\begin{array}{c}\text { Of the four basic skills in } \\
\text { learning English, which one do } \\
\text { you think is the most } \\
\text { important? }\end{array}$ & $\begin{array}{l}\text { Listening } \\
\text { Speaking } \\
\text { Reading } \\
\text { Writing } \\
\end{array}$ & $\begin{array}{c}10 \\
69 \\
3 \\
2 \\
\end{array}$ & $\begin{array}{c}8.7 \\
79.31 \\
3.45 \\
2.30 \\
\end{array}$ & $\begin{array}{c}7 \\
48 \\
5 \\
2 \\
\end{array}$ & $\begin{array}{c}11.11 \\
76.19 \\
7.94 \\
3.17 \\
\end{array}$ \\
\hline $\begin{array}{c}\text { What do you think } \\
\text { communicative competence } \\
\text { emphasizes? }\end{array}$ & $\begin{array}{l}\text { Listening } \\
\text { Speaking } \\
\text { Reading } \\
\text { Writing } \\
\end{array}$ & $\begin{array}{c}2 \\
81 \\
2 \\
1 \\
\end{array}$ & $\begin{array}{l}2.30 \\
93.1 \\
2.30 \\
1.15 \\
\end{array}$ & $\begin{array}{c}1 \\
60 \\
1 \\
1 \\
\end{array}$ & $\begin{array}{c}1.59 \\
95.23 \\
1.59 \\
1.59 \\
\end{array}$ \\
\hline $\begin{array}{l}\text { What is your main purpose for } \\
\text { learning English at university } \\
\text { (first choice)? }\end{array}$ & $\begin{array}{c}\text {-To get enough credits because I have to learn English } \\
\text {-To pass exams such as CET Band } 4 \text { and CET Band6 } \\
\text { and get a better job in the future } \\
\text {-To practice and improve my spoken English in order } \\
\text { to and get a better job in the future } \\
\text {.Others }\end{array}$ & $\begin{array}{l}1 \\
21 \\
51 \\
8\end{array}$ & $\begin{array}{r}1.15 \\
24.14 \\
58.62 \\
9.19 \\
\end{array}$ & $\begin{array}{l}8 \\
5 \\
39 \\
6\end{array}$ & $\begin{array}{l}12.70 \\
7.94 \\
61.90 \\
9.52 \\
\end{array}$ \\
\hline $\begin{array}{c}\text { (to lower-intermediate } \\
\text { Students) Do you think College } \\
\text { English teaching meet your } \\
\text { expectations? }\end{array}$ & $\begin{array}{l}\text { Yes } \\
\text { No Idea } \\
\text { No }\end{array}$ & $\begin{array}{c}59 \\
24 \\
4\end{array}$ & $\begin{array}{c}67.82 \\
27.58 \\
4.60\end{array}$ & & \\
\hline $\begin{array}{l}\text { (to higher-intermediate } \\
\text { Students) Do you feel satisfied } \\
\text { with College English teaching? }\end{array}$ & $\begin{array}{l}\text { Yes } \\
\text { No Idea } \\
\text { No }\end{array}$ & & & $\begin{array}{l}17 \\
22 \\
24 \\
\end{array}$ & $\begin{array}{l}26.98 \\
34.92 \\
38.10 \\
\end{array}$ \\
\hline
\end{tabular}

Regarding the first question, $29.88 \%$ of students at the lower-intermediate level had heard the term "communicative competence", while only $26.98 \%$ of students at the higher-intermediate level had heard this term. This term is not too familiar among these students, though it can be assumed that more students are familiar with the Chinese term and not the English translation. It is undoubtedly necessary that the purpose and benefits of implementing CLT should be explained to students.

Question two is designed to discover students' thoughts about the four basic skills in English learning. Not surprisingly, students at both levels believed speaking is the most important skill $-79.31 \%$ of the lower-intermediate students and $76.19 \%$ of the higher-intermediate students chose this skill. The listening skill was chosen by around $10 \%$ of the students in both levels. Few students regarded reading or writing as the most significant skill when learning English. Also, few students chose two skills altogether because they might believe, for example, that speaking and listening skills inherently go together. Generally speaking, as students have to go to interviews or communicate with various people after graduation, speaking seems to be the most important skill for them.

Although not too many students had heard the term "communicative competence", many seemed to understand what communicative competence emphasizes. More than $90 \%$ of the students at both levels believed that the communicative teaching approach focuses on speaking skills (because students are exposed to various communicative activities, such as group discussions, role playing, and debating). However, the components of communicative competence, which are linguistic, sociolinguistic, discourse and strategic competence (Dai \& Chen, 2008; Hedge, 2000), and the purpose of CLT are far more complicated.

When referring to the main reason for learning English at university, more students at both levels chose the option "to practice and improve my spoken English in order to get a better job in the future". Of the lower-intermediate students, 24.14\% learn English because they want to pass exams such as College English Test Band 4 and Band 6 and to get good jobs in the future. This is both understandable and predictable. Of the higher-intermediate students, $12.70 \%$ learn English simply because they have to, while $7.94 \%$ do so in order "to pass exams and get better jobs". Students at the lower-intermediate level want to learn about Western culture and learn English to communicate with others because English is an international language. For students at the higher-intermediate level, they may learn English in order to travel, for fun, or to use it as a communication tool.

The last question was meant to determine lower-level students' expectations and higher-level students' satisfaction with CET. Among the lower-intermediate students, $67.82 \%$ thought positively about learning English at university and believed that CET can meet their expectations. However, many higher-intermediate students felt dissatisfied with CET. Their reasons were that they did not learn useful things and that their English ability had not improved, there was not enough opportunity to practice English in class, class is boring, and they did not like the teaching style.

\section{IMPLICATIONS}

From the questionnaire, we can see that quite a number of students still maintain high aspirations for learning English at university; improving speaking skills is one of the most important things for students. As Hedge (2000, p. 71) notes, "communicative language teaching sets out to involve learners in purposeful tasks which are embedded in meaningful contexts and which reflect and rehearse language as it is used authentically in the world outside the classroom". 
Therefore, I believe that CLT is useful for creating a learning environment and should be implemented in more Chinese universities. Also, curriculum design and class size should be adapted to better fit this teaching method. Developing college students' communicative competence should help students more easily use their English. Their pragmatic competence can also be developed through cultivating their English ability using this teaching method, allowing students to learn English in a more practical way. Scovel (2006, p.10) points out that "[communicative competence] does not neglect grammatical competence; it simply builds upon it by emphasizing that other skills need to be acquired if one is to become a fluent and accurate speaker of another language". Therefore, it is also necessary to have a post-communicative model (Figure 1: see, also, for example, Brumfit, 1979; Byram, 1988) when implementing CLT.

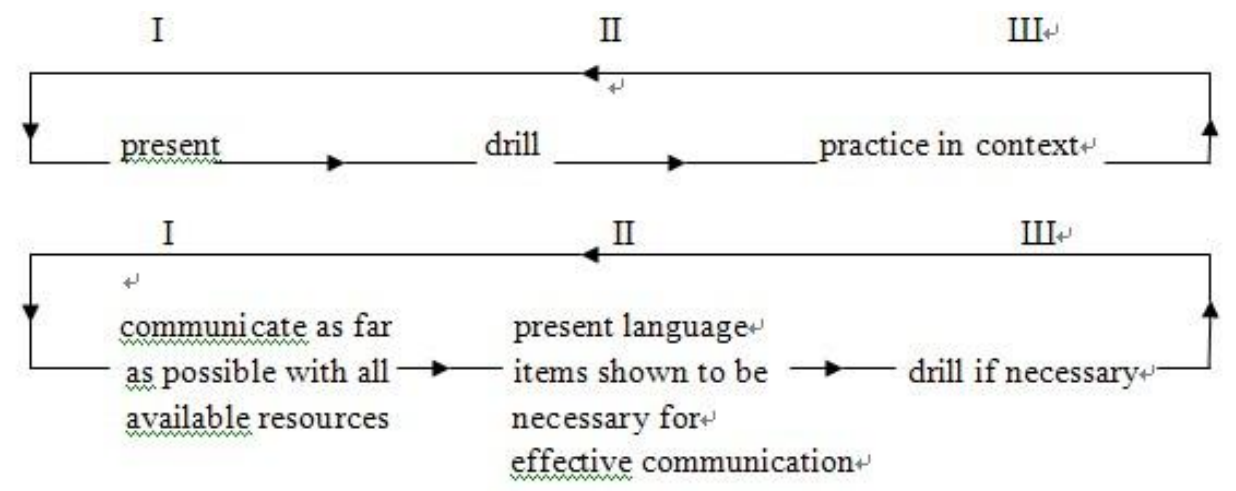

Figure 1 A traditional, Post-communicative Model by Brumfit, 1979

ELT in China needs to be discussed by both teachers and students so they might gain a proper understanding of the objective and how ELT can be further developed and reformed. According to Bygate (2001, 17-28), teaching English is not simply providing "the opportunity for learners to use language in order to communicate meaning without focusing on accuracy" and "a distinct methodology and syllabus may be needed".

\section{CONCLUSION}

The use of CET will produce new English speakers, especially in EFL countries such as China. We should also understand that it is necessary for CET to have reasonable objectives and requirements, and that it is necessary to improve current teaching methods to improve students' oral English proficiency.

Developing students' communicative competence is mandatory for ELT in Chinese colleges and universities, and should be a priority when teaching and learning English today. College English teachers should be armed with sufficient knowledge to guide students in the process of learning English. Therefore, it is promising to implement integrated skills into English teaching when promoting the communicative teaching approach. We should look at CLT as a task within the bigger framework of ELT. Therefore, from the discussions above, ]it will be appropriate to implement the communicative language teaching approach to help college students in China improve their English skills.

\section{REFERENCES}

[1] Brumfit, C. (1979). 'Communicative’ Language Teaching: an Educational Perspective. In: C. J. Brumfit, \& K. Johnson (eds). The Communicative Approach to Language Teaching. Oxford: Oxford University Press, 183-191.

[2] Bygate, M. (2001). Speaking. In: C. Ronald, \& D. Nunan. The Cambridge Guide to Teaching English to Speakers of Other Languages. Cambridge: Cambridge University Press, 14-20.

[3] Byram, M. (1988). "Post-Communicative" Language Teaching. British Journal of Language Teaching, 26 (1), 3-6.

[4] Canale, M. \& M. Swain. 1980. Theoretical Bases of Communicative Approaches to Second Language Teaching and Testing. Applied Linguistics, 1, 1-47.

[5] Chen, M. L., \& Hu X. Q. (2006). Towards the Acceptability of China English at Home and Abroad. Changing English, 13 (2), 231-240.

[6] China Ministry of Education. (2007). College English Curriculum Requirements. Beijing: Higher Education Press.

[7] Dai, J. X., \& Chen Z. L. (2008). Contemporary English Language Teaching: Theory and Practice. Hefei: University of Science and Technology of China Press.

[8] Davies, A. (2005). A Glossary of Applied Linguistics. Edinburgh: Edinburgh University Press.

[9] Hedge, T. (2000). Teaching and Learning in the Language Classroom. Oxford: Oxford University Press.

[10] Hymes, D. (1972). On Communicative Competence. In: J. B. Pride, \& J. Holmes. (eds.) Sociolinguistics. Penguin: Harmondsworth, 269-293.

[11] Kramsch, C. (2006). The Uses of Communicative Competence in a Global World. Review of Applied Linguistics in China, 2 , 30-50.

[12] Kunschak, C. (2004). Language Variation in Foreign Language Teaching: On the Road to Communicative Competence. Frankfurt/Main: Peter Lang Publishing.

[13] McArthur, T. (2002). Oxford Guide to World English. Oxford: Oxford University Press.

[14] McKay, S. L. (2002). Teaching English as an International Language: Rethinking Goals and Approaches. Oxford: Oxford 
University Press.

[15] Scovel, T. (2006). Learning Communicative Competence: Insights from Psycholinguistics and SLA. Review of Applied Linguistics in China, 2, 7-29.

[16] Yang W.Y., \& Fang F. (2008). Optimization of Multimedia English Teaching in Context Creation. International Education Studies, 1 (4), 136-142.

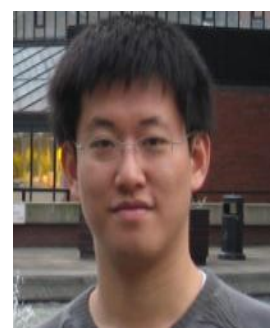

Fan Fang, born in Shantou, Guangdong, China, obtained his M.A. in English Language and World Englishes from the School of English, University of Leeds, the U.K, in 2007.

He currently works as a LECTURER at the English Language Center, Shantou University, Shantou, Guangdong, China. His academic papers are published in both national and international journals such as English Today (Cambridge University Press, 2008), International Education Studies (Canadian Center of Science and Education, 2008), Asian Culture and History (Canadian Center of Science and Education, 2009). His research interests include World Englishes, sociolinguistics, and teaching English as a second or foreign language.

Mr. Fang is currently the member of TESOL (Teaching English to Speakers of Other Languages), IAWE (International Association of World Englishes) and ASIA TEFL (Teaching English as a Foreign Language). 